\title{
Toward A Conceptual Synthesis and Ecological Approach to Case Studies of Curricular Innovation Implementation and University Restructuring in Russian HE
}

\author{
Tamara Savelyeva ${ }^{1}$ \\ ${ }^{1}$ The Hong Kong Institute of Education, 10 Lo Ping Rd, IELL, HKIED, Hong Kong, SAR \\ Correspondence: Tamara Savelyeva, The Hong Kong Institute of Education, 10 Lo Ping Rd, IELL, HKIED, Hong \\ Kong, SAR. E-mail: tsavelyeva@gmail.com
}

Received: October 29, 2013

Accepted: November 19, 2013

Online Published: November 20, 2013

doi:10.5430/ijhe.v2n4p228

URL: http://dx.doi.org/10.5430/ijhe.v2n4p228

\begin{abstract}
This study addresses the methodological and conceptual challenges associated with the application of disconnected frameworks of organizational theory and case studies, focused on "efficiency, effectiveness, and economy" to investigate complex educational phenomena in post-Soviet higher education systems under the condition of restructuring. I use the example of university restructuring and institutional curricular innovation implementation in Russian higher education to test and validate an alternative model, which employs ecological principles as the guiding value system and utilizes conceptual synthesis at all stages of this case study. The resulting descriptive model comprises antecedents, processes, and contents of university restructuring under three broad categories: organization, environment, and relation. Elaborated with an ecological approach, this model enriches the current vision of curricular innovation implementation from lineal to the perspectives of emergence, networking, and self-organization principles of ecological science. In discussing the results of the study, I offer a new research model with its possible methodological constraints as well as its great potentials to advance the sub-field of educational policy and educational administration.
\end{abstract}

Keywords: Conceptual synthesis, University restructuring, Higher education leadership, Ecological approach, emergence, Networking, Self-organization, Descriptive model, Russian higher education, Curricular implementation, Post-Soviet environment

\section{Introduction}

From the 1990s onward, drastic changes in educational philosophies of the former Soviet system forced Russian universities to modify their structures and governance for entering the global educational market. The market-driven educational ideologies and economic rationalist approaches employed to achieve the desired modifications created a variety of de-centralized restructuring responses across the country. After years of chaos, the new Federal Educational Law 2012 gave the HE institutions a legal foundation for restructuring their systems, offering university administrations "a sense of national recovery and direction" (Morgan and Kiucharev, 2012, p. 3). Most importantly, the Law officially allowed HE institutions to "commercialize" their structures and operations in order to compete on a global educational market. The new policy required the universities to align their traditional curricular contents and structures with the new directions by introducing western-designed courses, programs, curricular structures, teaching- learning methods, and initiatives into their practices. However, focused on principles of access, quality, and efficiency, the new policy framework did not resonate with the former Soviet academic value system (Note 1) of the teaching faculty and thus made the required introduction of the western-design curricular innovations a complicated business. This disconnect between new market-driven policy agendas that guide changes in the HE system and legacies of the former Soviet curricular practices that remain resilient in the university classrooms create both methodological and conceptual challenges for educational researchers. In the field of educational policy and administration, the commonly utilized organizational frameworks and a case study method restrict research foci to issues of linear policy implementation and antecedents of the university restructuring in a post-Soviet environment. A huge number of the isolated organizational theories (Shafritz, Ott, and Jang 2011) do not put forward "a single theory which explains the entire area of analysis and development of organizations" (Lǽggard and Bindslev, 2006, p.13) creates another limitation to studies of restructuring phenomena in a complex policy environment. 
In this paper I address these methodological and conceptual limitations by replacing a common organizational research framework based on principles of efficiency, effectiveness, and economy (Welsh, 1997) with a more contemporary ecological framework, which utilizes principles of emergence, networking, and self-organization (Savelyeva, and Lee, 2012) at all phases of the research on university restructuring. Using conceptual modeling, I create a visual representation for the antecedents of a curricular innovation introduction in a university under the condition of restructuring. Applying a conceptual synthesis technique to modeling, I construct an underlying frame for the study of university restructuring that consists of a synthesis of systemic ideas, leadership theory, and educator's empowerment theory. The conceptual synthesis approach for building conceptual frames differs from a traditional technique of combining different theoretical constructs in one contextualized study that researchers commonly used for grounding research cases. The latter approach is a linear "mix and match" technique, which might not generate solid theoretical grounds and synthesize all the employed theoretical constructs to study a complex phenomenon. Employing conceptual synthesis in this study I aim to addresses the limitations of linearity that challenge inquiries into innovation introduction in HE.

I used a single case of the Sustainability curricular project implementation, a three-year curricular initiative, implemented on the grounds of the Ural Federal University of the First President of Russian Federation (UFU) in 2008 -2010. Documented examples of educational settings under condition of restructuring, where curricular innovations has been introduced and observed for a period of time, and as well as examples of research studies on innovation introduction in post-Soviet environments, are relatively few, compared with the level of theoretical discussion. The Sustainability project is one of a few mainstream examples of curricular innovation implementation in post-Soviet academic environments. The project involved development and implementation of a western-designed undergraduate course curriculum on a general theme of sustainability education. This project was part of a university restructuring effort to comply with new state regulations, meet new HE standards, and survive the turmoil of the restructuring HE system in Russia.

My intent was to address the conceptual and methodological limitations of policy investigations into restructuring of a post-Soviet academia by describing an alternative approach to the inquiry of the complex restructuring phenomena. Using this primary reason as the basis for conducting my study, I shaped my inquiry with an assumption that curricular innovation implementation in a Russian university might be approached with a more naturalistic lens of scientific inquiry rather than an economic rationalist way of analysis. The scientific naturalist philosophies have been a core of Russian faculty training for more than a century. The faculty's core beliefs and values formed by the philosophies of scientific naturalism keep shaping their academic and teaching practices at the times of policy restructuring. A philosophy of economic rationalism, in contrast, has been offering a drastically different set of values that the participating faculty found difficult to implement in the classrooms. Using ecological principles rather than principles of economic rationalism to ground the study of curricular innovation implementation in post-Soviet university under condition of restructuring allowed me to grasp the insights based on the perceptions of participants.

My approach included an application of ecological principles (emergence, networking, and self-organization) throughout all stages of the study of restructuring in post-Soviet academia and synthesizing the three selected conceptual frames (systemic approach, transformative leadership, and teacher's empowerment) into a resulted conceptual model of curricular innovation implementation in the UFU. Before discussing the study, I would like to introduce a broader context of my study that reflects an ecological approach to scientific inquiry and synthesis of organizational conceptualizations.

\section{Ecological Approach to Scientific Inquiry}

The ecological approach to scientific inquiry became prominent in educational research, particularly in studies of innovation introduction in the educational administration and policy-related arenas. The use of the ecological approach implies an application of metaphorical representations of ecological principles to describe the process of change in HE institutions. It is often used in scientific discourses to communicate "the richness of [its] connotation and in support of societal importance and ... values" through reflecting on "a wide array of processes, values, and kinds of interactions" (Pickett and Cadenasso, 2002, p. 6).

The rise of the ecological science approach in educational studies is supported by recent publications and targeted journals, such as Ecology and Society and recently published thematic volumes in a Studies in Educational Leadership book series. There is a widespread agreement among those authors that ecological theory provides new insights in education research, specifically organizational studies on leadership response to an introduction of innovative methodologies and the nature of change in educational systems (Fullan, 2007; Hargrreaves and Fink, 2004.). Some scientists have applied the ecological metaphor approach in order to understand what is observed in the classroom or educational organization. For example, Hannan and Freeman (1993) used a metaphor of organizational 
ecology to understand the nature of change in educational settings. Those scientists, who are concerned with measurement of interactivity within different levels of a school system, apply the ecological modeling approach. For example, Koper (2003) created an "integrated eLearning system" model to describe how technology supports primary educational functions. For any of these approaches, there are a variety of conceptual frameworks that derive theoretical generalizations from ecological sciences.

One of the main reasons researchers choose ecological frameworks to guide their studies is that they allow more holistic and systemic investigation into phenomena. Analogies between processes surrounding the educational phenomena and ecological principles generally encompass a wide range of perspectives that reflect the paradigmatic breadth of university restructuring and curricular innovation implementation as complex educational phenomena

Another benefit of applying an ecological frame to educational studies is that, while exploring university restructuring and curricular implementations through the lenses of ecological principles, it is possible to translate the phenomena into a model that incorporates a full range of its antecedents. Ecological framework complements a descriptive modeling methodology by translating the general meanings of curricular implementations and their adaptation in the post- Soviet classrooms into working research tools that aid public discourse and advance decision-making. Enriched with an ecological lens, descriptive modeling, in turn, also benefits the research in three ways. First, it allows representations of structural, social, and other emerging realms of the educational phenomena that I described with precision and accuracy. Second, modeling helps extract some useful generalizations to a curricular innovation implementation process in the UFU. Third, it clusters the antecedents, processes, and contents of the university restructuring that might make the implemented curricula last in institution.

The central assumption that inspired the use of the ecological approach and modeling (Savelyeva, 2011) in this study is that $\mathrm{HE}$ is a non-linear structure consisting of interactive, complex, and adaptive systems (Morrison, 2002; Savelyeva, 2012, Savelyeva and Park, 2012). HE, therefore, displays all the characteristics of system behavior, including self-perpetuation. I focused on different dimensions of institutions' and individual interactions, contexts, processes of organization, and the functionality of innovative instances across micro- and macro-levels of policies and praxis. The assumption of HE non-linearity guided my research interpretation process, where I intended to grasp a "whole picture" of the phenomenon. It also validated the choice of educational modeling as one of my analysis methods. For the modeling, I used three organizational change dimensions: antecedents, content, and process of the innovation introduction at the UFU. The antecedents (de Ven and Huber, 1990), or forces and sources (Kezar, 2004) examined the "whys" of the innovation introduction. The content dimension referred to "whats" of innovation introduction, and it included its scale, focus, range, timing, and degree of the change. The process dimension referred to "hows" of the change, and it determined the adopted strategies and the role of the stakeholders.

As part of the ecological approach, I selected three ecosystem principles (Savelyeva and Lee, 2012) - emergence, networking, and self-organization - to magnify the conceptual lenses of the participants in the study, so that I could gain their understanding and interpretation of the innovation introduction. My intent was to fully capture the experiences of those involved in the process of innovation introduction and use these participants' meanings to understand the phenomena. Throughout data collection and analysis, I kept the principles of emergence, networking, and self-organization central in my research questions. Table 1 explains these three ecological principles in relation to the research questions.

Table 1. Ecological principles in relation to the study's research questions

\begin{tabular}{|c|c|c|}
\hline $\begin{array}{l}\text { Ecological } \\
\text { principle }\end{array}$ & Explanation & Research Questions \\
\hline Emergence & $\begin{array}{l}\text { This principle supports the idea on non-linearity of } \\
\text { an educational system, where the observed } \\
\text { phenomena arise from, but are not necessarily } \\
\text { dependent on, the educational processes and } \\
\text { entities involved in the study }\end{array}$ & $\begin{array}{l}\text { Do the participating faculty generate } \\
\text { ideas for fostering curricular praxis as } \\
\text { part of a continuous and dynamic process } \\
\text { of restructuring? }\end{array}$ \\
\hline Networking & $\begin{array}{l}\text { This principle emphasizes the interdependent } \\
\text { nature of an educational system described by } \\
\text { networks of relationships }\end{array}$ & $\begin{array}{l}\text { What features of the course encourage } \\
\text { networking and communication within } \\
\text { and outside participants' institution? }\end{array}$ \\
\hline Self-Organization & $\begin{array}{l}\text { This principle facilitates an adaptation or } \\
\text { appearance of a new educational structure and } \\
\text { pattern without directly imposing innovations and } \\
\text { practices with the power of a central authority or } \\
\text { with the help of external elements }\end{array}$ & $\begin{array}{l}\text { How does the course support } \\
\text { modifications of the existing institutional } \\
\text { infrastructures, organizations, and } \\
\text { established praxis at different levels of } \\
\text { academic hierarchy? }\end{array}$ \\
\hline
\end{tabular}




\section{Synthesizing the Conceptual Frame: Systemic Ideas, Leadership Theory, and Educator's Empowerment}

Considering the benefits of the ecological approach for investigating innovation introduction, I connected the study with three theoretical groundings, specifically, systemic ideas in educational research, leadership conceptualizations in relation to HE innovation, and the concept of educator's empowerment. The synthesis of these three conceptual frames helped create a conceptual model of the phenomena in study.

The systemic approach to educational change was the first component of my theoretical framework for this study. I assumed a systemic view of the subject matter for defining and exploring nesting contextual levels of innovative projects' introduction into HE systems. The systemic approach allowed for a critical synchronization of the worldview of ecological thought (ecologism), interrelational and value-based ontologies, and the ecological methodology. The systemic approach informed a composition of an ecological model of the innovative project that I developed alongside Bateson's theory of recursive learning levels (Harries-Jones, 1995). Bateson's theory treats learning and change as a non-linear process, where "higher orders of learning are neither necessarily superior to, nor more desirable than, lower levels" (Tosey and Mathison, 2008, p.14). Considering the insights from revisionary systemism and ecologism, I intended to accomplish the goal of my study by (1) discussing the basis of the resulting model for understanding transformative change beyond the limits of an educational system; (2) reflecting on the trajectories and vectors of the innovative project design and its implications, and (3) proposing a mechanism for advancing intentional change in HE educational systems.

The second component of my conceptual framework was concerned with academic discourses at the level of organizational leadership. Specifically, I applied the framework of a transformative leadership practice (Heck and Hallinger, 1999; Stewart, 2006) that views sustainability as a result of strategically distributed, cross-level innovation guidance. I examined the following dimensions of this framework to discover the signs of transformational leadership within the Sustainability and the Environment project (cited in Leithwood and Jantzi, 2000 p. 114):

(1) building university vision and establishing institutional goals;

(2) providing intellectual stimulation;

(3) offering individualized support;

(4) modeling best practices and important organizational values;

(5) demonstrating high-performance expectations;

(6) creating a productive school culture; and

(7) developing structures to foster participation in school decisions.

The challenge of building an organization culture that focuses on an educational project's longevity through continual improvement of programs and capacities of staff (Stewart, 2006) is considered the most significant of those seven dimensions. As leaders are often insufficient in meeting the challenge of building cultures, I considered the dispersal of leadership authority (Harris, 2003; Harris and Chapman, 2002; Lambert, 2002; Sergiovanni, 2007) as a separate dimension that potentially promotes transformative leadership practices.

The next component of the conceptual framework was developed around the concept of empowerment and reflective action. Within this frame of reference, the educator's practices are guided in large measure by a "tacit knowledge" of education, which he or she forms in response to personal and contextual factors. Within this framework, the educator's fundamental values and beliefs are a focal point of educational change. I address cognitive, administrative, and, above all, affective aspects of teaching and learning. According to findings in the field (Efron and Joseph, 2001; Fischer and Kiefer, 2001; Ryan, 2005; Sugrue, 1998), these aspects shape educators' implicit knowledge and might affect innovation introduction in HE. By uncovering and articulating the meaningful basis of the participants' actions in response to innovation, I unfold conditions that guided work of faculty and staff who were involved in the project and contributed to its perpetuation. The ideas of empowerment and reflective action shed light on matters of appropriateness and effectiveness of innovative practice, as I explored the implications of the constructed meanings together with the overt dimensions of the participants' attributions, planning, and decision-making.

\section{Research Scope}

I used the case of the Sustainability project as an example of curricular innovation implementation in the post- Soviet university under condition of restructuring. The project was an undergraduate course on the general theme of sustainability education, developed by Russian faculty and launched in 2008 in the UFU with support of the Curricular Research Centre, Central European University (Hungary). 
The two objectives of my research were (1) to determine the features of the course curricular implementation, which reflect the policy agenda for a market-driven university restructuring; and (2) to provide a conceptual model of the curricular innovation implementation in the UFU university. Considering these two objectives, I established a guiding research question: How do faculty implement western-design innovative curricular methodologies in their classroom in the context of persistent university restructuring?

\subsection{Research Design}

I utilized a qualitative research design methodology with a single-case study approach to develop a holistic conceptual model for describing processes of implementing the innovative curricular Sustainability course at UFU. Single-case study design is commonly used in educational research to investigate a previously unexplored phenomenon in a setting that, sometimes is inaccessible (Yin 1994). Focused on the understanding of the curricular implementation phenomena in a single university setting, this research was a single case-study. My decision to adopt a single-case study was based on the uniqueness of the UFU administrative response to restructuring. UFU is the largest university in the region, which, along with only a few universities in Russia secured a status of Federal HE institution and gained access to federal funds. The uniqueness of its status made context an important research consideration in this study. Connecting the curricular innovation implementation phenomenon to context became essential for gaining a holistic image of university restructuring in general and curricular innovation implementation in particular. There are two types of single-case studies: holistic or embedded. Holistic case studies use one institution as the only case. Embedded case studies look at different units within one institution as multiple cases (Yin, 1994). For this study, I adopted a holistic single-case study approach because I studied the curricular innovation implementation as a single case in one HE institution.

To achieve the sample needed for this study, I used a combination of purposive and network selection and relied on my judgment, experience, and knowledge to select a preliminary sample of participants. This sampling technique is used frequently in case study research in which researchers want to study either typical or critical cases (Whitley, 2002). The study involved project stakeholders, faculty members, and students of the UFU.

\subsection{Data Collection and Instrumentation}

In this study, I employed three forms of data collection: (1) eight semi-structured, open-ended, face-to-face, and Skype-supported interviews with project stakeholders and faculty members, (2) two real-time observations of faculty videoconference sessions; eight observations of virtual class meetings, and 10 real-time project meetings; (3) analysis of textual narratives, documents, and artifacts, which were available to and created by the course participants to design, introduce, and adapt the project in their universities,

\subsection{Data Analysis Procedures}

I analyzed the data in three major stages: First, I identified themes and generated codes; second, I cross-analyzed codes for potential relationships and mapped them over the themes; and third, I created a model. To analyze data, I used a qualitative data analysis program, Non-numerical Unstructured Data Indexing Searching and Theorizing Vivo (NVivo ${ }^{\circledR}$ ). The NVivo ${ }^{\circledR}$ software package includes various tools for holistic reflective-interpretive approaches to data analyses, which I practice in the study. To ensure the clarity of the interpretation and make analysis more transparent to the stakeholders, I employed a thematic approach to latent data analysis, which I performed across its articulated, attributional, and emergent levels of data interpretation. As for available textual narratives, field notes, and recordings resulted from document/artifacts collection, I analyzed them all together in the cross-case analysis of potential relationships among research constructs. The desired model was derived from the data with the "union" feature of the NVivo ${ }^{\circledR}$ software.

\section{Findings: A Conceptual Model of Curricular Innovation Implementation}

The analysis revealed three contextual categories related to curricular innovation implementation in the UFU: organization, environment, and relation (Fig. 1). The organization category included a sub-theme of global competition and survival; the environment category included subthemes of project transparency and flexible project dynamics; and the relation category included subthemes of internal and external, formal and informal relationships. 


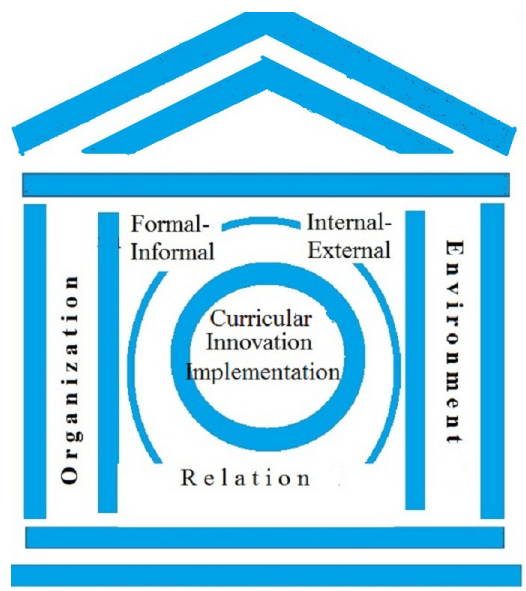

Figure 1. Contextual Categories of Curricular Innovation Implementation at the Ural Federal University

\subsection{Organization}

This category included the issues related to the university's internal administrative processes that restricted effective coordination, free operation, and fast implementation of the curricular innovation implementation. Although classic organizational theory stresses issues of functional control within formal organizational structures (e.g. Simon, 1957), the UFU faculty were motivated by a different trigger for welcoming a western-designed course into their programs, as well as new methodologies into their classrooms. The urgent need for the UFU to change and adapt the new innovative structures and methodologies for surviving the ongoing restructuring played a major role in generating a relevant policy. However, at the level of classroom practice, the policy had little effect on how and when the faculty taught the proposed course. One of the reasons faculty remained committed to implementing the course was a transparency of the project structure and its flexible dynamics. Course transparency significantly speeded up the course implementation. I explained the unusual structure of the new course both to the participating students and the involved faculty at the beginning of the study. However, that was not enough to make the course visible across the university. Faculty admitted that the "marketing" of the innovative course features (a new case study methodology, different assessment techniques, and the use of social networking) in a more formal, yet comprehensive fashion, would attract more faculty. Answering a priori "What," "Why," and "How" questions in more detail (Why did we choose this design for the course? Why are we using case studies and student assessments? Who are our sponsors?) and engaging the university marketing unit would address a more general issue of making the entire process of designing and operating this innovative course more transparent.

\subsection{Environment}

The findings showed that the participants' awareness about the external challenges, which I further call "externalities," and pressures associated with the general restructuring of the HE system has triggered curricular implementation into their practices. Although aware about the overall notion of global competitiveness surrounding the university life, participants barely responded to the resource scarcity and changes in university academic regulations. They immersed themselves into teaching and experimenting with the new curricular methodologies mainly due to an academic curiosity and natural openness to the new. This finding contradicts the existing research arguments about university restructuring, which list global competition (Smart and Hitt, 1994), changes in federal regulations, and lack of resources (Meyer, Brooks, and Goes, 1990) as triggers of change. Although the externalities had an impact on the academic life of the participating faculty, they did not trigger a massive change in their classroom practices. The research showed that the participants' notion of an "externality" expanded beyond federal and state powers to a larger global academic community and overall economic crisis. However, faculty remained loyal to their traditional ways of teaching and learning and did not experiment with the new methods outside of their Sustainability course.

\subsection{Relation}

This category reflects the importance of internal-external, formal-informal relationships during the process of implementing a curricular innovation in the classroom. In the case of UFU, the formal-informal type of relationships among faculty was a key element in innovation. Often, the change from a formal to informal mode of relation among stakeholders resulted in changes in implementation dynamics. For example, a shift from an official control over the 
course by university officials to informal participants' self- reporting boosted up the speed of the course implementation. The project attracted faculty members from other institutions without formal affiliation with this initiative. Social networking solidified the fluent communication and visibility of the participants within the project and kept it running. Online social networking reengaged participants into the conversation about the educational matters. At the theoretical level, this finding supports the concepts of relational cohesion, where repeated exchanges among participants serve as a unifying force, enhance commitment, and reduce uncertainty (Lawler and Yoon, 1996).

\section{Discussion}

Viewed through the lens of an ecological framework, which consisted of principles of emergency, networking, and self-organization, the important aspects of the resulted conceptual model included (1) the emergent nature of its elements, which were not necessarily derivable from the laws or organizational principles of HE; (2) non-linearity of its networks and unpredictability of structural responses; and (3) increased structural complexity due to self-organized relational dynamics of its elements.

The ecological principle of emergence addressed one of the major limitations of modeling, specifically, lack of transferability. Generally referring to the appearance of higher-level properties, entities, or behaviors from the collective dynamics of a system's components, emergence describes phenomena as more than the sum of its components. Although admitting a certain level of ambiguity, organizational researchers use a principle of emergence quite often, usually under a systemic framework of their studies. In my study of innovation introduction in HE, the emerging properties and behaviors observed within three resulted categories (organization, environment, and relation) were tied together by the laws of organizational and social dynamics. However, I argue that the phenomenon of curricular innovation implementation is not necessarily derivable from the laws or organizing principles of $\mathrm{HE}$ as a social system. Emergence of a qualitatively new phenomenon during the innovation introduction in the reconstructing university also had its place. The participants formed a community of sustainability scholars on a project social network site and kept using the e-space for creating and exploring a fundamentally new concept of noosphere education. The exhaustive knowledge about innovative teaching and technology did not contribute, yet, somehow triggered this shift of academic direction among the participants during the innovation introduction. Constantly changing internalities, as well as externalities of the UFU, set fertile grounds for emergence of new course properties, behaviors, and entities.

The principle of networking allows researchers to view universities, by analogy with ecological communities, as interconnected networks. Although the conceptual model captured some of the networks' structural features and made it possible to reflect on how these features were developed and how they operated, it did not aid predictability of the curricular response to restructuring. This finding challenges the general assumption of organizational modeling (Carrington, Scott and Wasserman, 2005) that visible and invisible network ties that hold components of the implemented project and its participants together define organizational behavior. As seen in this study, conceptual modeling had a limited ability to predict stability or instability of curricular innovation implementation based solely on the connectivity of the organizational networks. One possible explanation might be that organizational studies use networking principles to create lineal mechanistic models of educational phenomena that reflect the quantity and density of the social networks within organizations (Carrington, Scott and Wasserman, 2005). Such models are criticized for their inability to reproduce the richness and dynamics of multiple micro-communities of participants in all its complexity. I argue that networking, as an ecological characteristic and a separate university function, might encourage a scientifically optimistic outlook for understanding the insights of the complex educational phenomena of curricular innovation implementation. The predictability of the phenomena, however, remains limited.

The self-organization principle has manifested in this study when participants acted without any external order or clustered outside the formal university setting to promote innovation introduction. The participants expressed great autonomy during the course implementation, and they self-organized due to a high level of uncertainty and structural chaos, resulting from the perpetual restructuring of their university system. Implementing the new course provided the participants with a notion of a reduced uncertainty. In this case, self-organization increased the frequency of exchange among the participants. As a result, it enhanced their relationships and increased knowledge about the western-designed curricular methods. A reduction in uncertainty through improved relationships among stakeholders, which led to an increase of knowledge (Williamson, 1975) and reduced information asymmetry, can be regarded as a major benefit of self-organization during university restructuring. The reduced uncertainty about the restructuring, which was achieved through self-organization of project participants as well, might reduce the notion of pressing competitiveness from other $\mathrm{HE}$ institutions and lessen monitoring of curricular implementations in the future. 
Following the lack of organizational monitoring and control, the degree of complexity of curricular innovation implementation might increase as the requirements become less known and directions less certain.

Overall, replacing a commonly used research focus on efficiency, effectiveness and economy value system with a set of universal ecological principles brought about a fundamental question of the purpose of the restructuring and linked the resulted model with a broader discussion about change in post-Soviet HE system. University restructuring, as a process and an outcome, itself might serve questionable values and ends. As the organizational theorists Argyris and Schön (1996) stated:

The value we attribute to an increase in effectiveness or efficiency depends on how we answer the question 'effectiveness or efficiency for what? ...' The crucial point is that, as we try to understand or enhance organizational learning, we should keep in mind the variety of ways in which any particular example of it may prove to be invalid, unproductive or even downright evil. (p.64)

Therefore, I would argue that in light of its ecological properties, restructuring might be treated as a neutral process, which in any particular case concerns questions of context and intent. The assumption of "neutrality" of the phenomena in study requires careful consideration of theoretical grounds for each scientific study case.

The synthesis of different conceptual elements in this study showed that the frameworks, which are imbedded in one model, can be theoretically diverse. Although the imbedded parts, which Moravcsik (2003) called "conjectures," often need to be necessarily coherent at some fundamental level, when tested empirically, these conjectures might not share a full range of identical ontological assumptions. Theoretical synthesis might be a constraint to educational research on university restructuring due to a dominance of empiricism. However, I believe that the benefits of experimenting with different methodologies in social science open up opportunities for an exciting scientific debate. As Moravcsik (2003) pointed out:

The greater theoretical and methodological constraints social scientists impose on themselves, that is - the greater the range of alternative explanations, the more logically coherent the favored account, and the more difficult the methodological hurdles - that is, the greater the resulting confidence skeptics should have in any positive result. (p.134)

One way forward to work around the constraints of applying conceptual synthesis in research on complex phenomena might be to break down the elements of the synthesis and separately test each concept as well as the entire frame. The model on innovation introduction resulted from this study illustrates the possibility of the successful application of theoretical synthesis and addressing its constraints. In this regard, the synthesis became a methodological tool, which helped me to gain insights and understand the concrete and real-life event of innovation introduction at the university. This implies, there are more opportunities for turning theory into a practical instrument of investigating myriads of complex issues in the world of educational affairs.

\section{Conclusion}

The conceptual model of the Sustainability course implementation at UFU offered educational researchers deeper insights into the university restructuring phenomena at the post-Soviet university. This study proposed an alternative model, which incorporated ecological principles of emergence, networking, and self- organization to replace the widespread economic rationalist standards of organizational analysis. The resulting incremental model of curricular innovation implementation addressed some methodological problems; its descriptive categories - organization, environment, and relation - suggested a non-linearity of its elements, which were not necessarily derivable from the principles of organizational research. The structural responses to university restructuring appeared somewhat unpredictable, yet, dynamic, complex, and rather self-organized. Viewed through ecological parameters, the resulted model could suggest a paradigmatic nature of changes in HE organizational research. Overall, this study has revealed new areas to be explored by educational researchers to overcome the limitations of educational theories and methodologies to conduct single-case studies in post-Soviet environments. The proposed ecological approaches and theoretical synthesis to test methodological and conceptual constraints of the educational research might be used for future explorations in the field.

\section{References}

Argyris, C. \& Schön, D. (1996). Organisational learning II. New York: Addison Wesley.

Carrington, P., Scott, J., \& Wasserman, S (Eds.). ( 2005). Models and methods in social network analysis. New York: Cambridge University. http://dx.doi.org/10.1017/CBO9780511811395

Fullan, M. (2007). The new meaning of educational change ( $4^{\text {th }}$ ed.). New York: Teacher's College. 
Hargreaves, A., \& Fink, D. (2004). Seven principles of sustainable leadership. Educational Leadership, 61(7), 8-13.

De Ven, A., \& Huber, G. (1990). Longitudinal field research methods for studying processes of organizational change. Organization Science, 1, 213-219. http://dx.doi.org/10.1287/orsc.1.3.213

De Ven, A., \& Poole, M. (1995). Explaining development and change in organizations. Academy of Management Review, 20(3), 510-540.

Dill, D. (1997). Higher education markets and public policy. Higher Education Policy, 10(3), 167-155. http://dx.doi.org/10.1016/S0952-8733(97)00011-1

Dill. D. \& Sporn. B. (1995). The implications of a postindustrial environment for the university: an introduction. In D. Dill and B. Sporn, (Eds.), Emerging patterns of social demand and university reform: Through a glass darkly (pp. 1-19). Oxford: Pergamon.

Efron, S., \& Joseph, P. (2001). Reflections in a mirror: Metaphors of teachers and teaching. In P. Joseph and G. Burnaford (Eds.), Images of school teachers in America (2 ${ }^{\text {nd }}$ ed.) (pp. 75-92). Mahwah, NJ: Lawrence Erlbaum.

Fischer, J. \& Kiefer, A. (2001). Constructing and discovering images of your teaching. In P. Joseph and G. Burnaford (Eds.), Images of school teachers in America (2 ${ }^{\text {nd }}$ ed.) (pp. 93-114). Mahwah, NJ: Lawrence Erlbaum.s

Ginns, P., Prosser, M., \& Barrie, S. (2007). Students' perceptions of teaching quality in higher education: The perspective of currently enrolled students. Studies in Higher Education, 32, 603-615. http://dx.doi.org/10.1080/03075070701573773

Hannan M. \& Freeman, J. (1993). Organizational ecology. Cambridge: Harvard University.

Harris., A. (2004). Distributed leadership and school improvement. Educational Management Administration and Leadership, 32, 11-24. http://dx.doi.org/10.1177/1741143204039297

Harris, A. \& Chapman, C. (2002). Effective leadership in schools facing challenging circumstances. Nottingham: NCSL.

Harries-Jones, P. (1995). A recursive vision: Ecological understanding and Gregory Bateson. Toronto, Canada: University of Toronto.

Heck, R. \& Hallinger, P. (1999). Conceptual models, methodology, and methods for studying school leadership. In J. Murphy and K. Seashore-Louis (Eds.), The 2nd handbook of research in educational administration. San Francisco: McCutchan.

Jones, D., \& Rowe, D. (2004) Sustainability Education handbook. Lansing, Mich.: Urban Options (available at http://www.urbanoptions.org/SustainEdHandbook/index.htm)

Kezar, A. (2004). What is more important to effective governance: Relationships, trust, and leadership, or structures and formal processes? New Directions in Higher Education, 127, 35-46. http://dx.doi.org/10.1002/he.154

Koper, R. (2003). Learning technologies: An integrated domain model. In W. Jochems, J. van Merrienboer, and R. Koper, Integrated eLearning (pp. 64-79). London: Routledge.

Lambert, L. (2002). A framework for shared leadership. Educational Leadership, 59 (8), 37-40.

Leithwood, K. \& Jantzi, D. (2000). The effects of transformational leadership on organizational conditions and student engagement with school. Journal of Educational Administration, 38(2), 112-129. http://dx.doi.org/10.1108/09578230010320064

Lawler, E. \& Yoon, J. (1993). Power and the emergence of commitment behavior in negotiated exchange. American Sociological Review, 58(4), 465-481. http://dx.doi.org/10.2307/2096071

Lǽggard J. \& Bindslev, M. (2006). Organizational theory. Frankfurt: Ventus.

Meyer, A., Brooks, G., \& Goes, J. (1990). Environmental jolts and industry revolutions: Organizational responses to discontinuous change. Strategic Management Journal, 1I, 93- 110.

Miles, M., \& Huberman, M. (1994). Qualitative data analysis: An expanded sourcebook (2 ${ }^{\text {nd }}$ ed.). Thousand Oaks: Sage.

Moravcsik, A (2003). Theory synthesis in international relations: Real not metaphysical. International Studies Review, 5(1),131-136. http://dx.doi.org/10.1111/1521-9488.501019_4 
Morrison, K. (2002). School leadership and complexity theory. New York: Routledge.

Morgan, J. \& Kiucharev, G. (2012). Higher education and the post- Soviet transition in Russia. European Journal of Education, 47(1), p. 3-8. http://dx.doi.org/10.1111/j.1465-3435.2011.001503.x

Pickett, S., \& Cadenasso, M. (2002). The ecosystem as a multidimensional concept: Meaning, model, and metaphor. Ecosystems, 5, 1-10. http://dx.doi.org/10.1007/s1021-001-0051-y

Ryan, A. (2005). Teacher development and educational change: Empowerment through structured reflection, Irish Educational Studies, 24 (2/3), 179-198. http://dx.doi.org/10.1080/03323310500435463

Sarason, S. (1996). Revisiting "The culture of the school and the problem of change." New York: Teachers College.

Savelyeva, T. \& McKenna, J. (2011). Campus sustainability: Emerging curricula models in higher education. International Journal of Sustainability in Higher Education, 12(1), 55-66. http://dx.doi.org/10.1108/14676371111098302

Savelyeva, T. (2012). Connecting instructional and cognitive aspects of a LE: A study of the Global Seminar Project, Learning Environment Research,15(1), 65-79. http://dx.doi.org/10.1007/s10984-012-9099-1

Savelyeva, T. \& Park, J. (2012). Ecologism and Complexity of Campus Sustainability Discourse. In W. Leal (Ed.), pp. 183-192. Environmental Education, Communication, and Sustainability, Vol. 34 Sustainable development at universities: New horizons. Frankfurt: Peter Lang.

Savelyeva, T. \& Lee, Y. (2012). Nature of leadership discretions and sustainability of educational innovations: Critical connections. In I. Duyar and A. Normore (Eds.), pp. 141-167. Advances in Educational Administration, Vol. 13. Austin, TX: Emerald.

Shafritz, J., Ott, S., \& Jang, Y. (2011). Classics of organizational theory $\left(7^{\text {th }}\right.$ ed.). Belmont, CA: Wadsworth.

Sergiovanni, T. (2007). Rethinking leadership. Thousand Oaks: Corwin.

Simon, H. (1957). Administrative behavior. New York: Macmillan.

Smart, D. \& Hitt, M. (1994). A mid-range theory regarding the antecedents of restructuring types: An integration of agency, upper echelon and resource-based perspectives. In P. Shrivastava, A. Huff, \& J. Dutton (Eds.), pp. 159-186. Advances in Strategic Management, Vol. 10A. Greenwich, CT: JAI.

Stewart, J. (2006) Transformational leadership: An evolving concept examined through the works of Burns, Bass, Avolio, and Leithwood. Canadian Journal of Educational Administration and Policy, 54, retrieved on October 26, 2012 from http://www.umanitoba.ca/publications/cjeap.

Sugrue, C. (1998) Confronting student teachers' lay theories and culturally embedded archetypes of teaching: implications for professional development. In C. Sugrue (Ed.), pp. 118-141. Teaching curriculum and educational research. Dublin: St. Patrick's College.

Thompson, P. \& McHugh, D. (2002). Work organizations: A critical introduction (3rd ed). Basingstoke: Palgrave.

Tosey, P. \& Mathison, J. (2008). Do organizations learn? Some implications for HRD of Bateson's levels. Human Resource Development Review, 7(13), 13-31. http://dx.doi.org/10.1177/1534484307312524

Welch, A. (1998). The cult of efficiency in education: Comparative reflection on the reality and rhetoric. Comparative Education, 24(2), 157-175. http://dx.doi.org/10.1080/03050069828252

Whitley, B. (2002). Principles of research in behavioral science. New York: McGraw-Hill.

Yin, R. (1984). Case study research: Design and methods. Beverly Hills, CA: Sage.

\section{Notes}

Note 1. The Soviet education value system was built around a goal of holistic upbringing (rearing) of a socialist-minded citizen to serve a collective good in a class-free society. 